УДК 338.1:330.332

DOI: https://doi.org/10.37320/2415-3583/13.8

Комліченко О.О.

кандидат економічних наук, доцент, Одеський національний політехнічний університет ORCID: http://orcid.org/0000-0001-5759-2922

Ротань Н.В.

кандидат економічних наук, Одеський національний політехнічний університет ORCID: http://orcid.org/0000-0002-0801-5958

\title{
ІНТЕЛЕКТУАЛЬНИЙ КАПІТАЛ ЯК ФАКТОР ВПЛИВУ НА ІНВЕСТИЦІЙНУ ПРИВАБЛИВІСТЬ ПІДПРИЕМСТВА
}

В умовах інтеграчії України у світовий економічний простір зростає увага до однієї з ключових характеристик залучення інвестиційних коштів - інвестиційної привабливості підприємства та шляхів ї̈ підвищення. Тому дослідження факторів, які впливають на зростання інвестииійної привабливості підприємства, є актуальним. У статті з'ясовані поняття «інвестиційна привабливість підприємства» та «інтелектуальний капітал». Окреслені фактори, які впливають на інвестиційну привабливість підприємства. Проведена їі бальна очінка, яка враховує не лите результати фінансово-господарської діяльності, а й рівень сформованості інтелектуального капіталу. За допомогою кореляиійно-регресійного аналізу визначений вплив інтелектуального капіталу на рівень інвестиційної привабливості підприємства харчової промисловості.

Ключові слова: інвестиційна привабливість, інтелектуальний капітал, фактор впливу, кореляційно-регресійний аналіз.

Постановка проблеми. Нестабільність економічної ситуації в Україні призвела до характерних зрушень на ринку промислових та продовольчих товарів. Дослідження інвестиційного клімату регіону дає змогу стверджувати, що сьогодні підприємства переробної і харчової промисловості мають найвищу інвестиційну привабливість. Тому виникає необхідність вивчення факторів, які впливають на інвестиційну привабливість підприємств цієї галузі, одним 3 яких $є$ інтелектуальний капітал. Оцінка впливу рівня сформованості та вартості інтелектуального капіталу підприємства на його інвестиційну привабливість 
дасть змогу обгрунтувати заходи, які сприятимуть піi підвищенню.

Аналіз останніх досліджень і публікацій. Теоретичні та практичні засади оцінки інвестиційної привабливості підприємства досліджуються в працях І.О. Бланка [1], А.О. Спіфанова, Т.М. Мельник [3], О.В. Носової [4], О.С. Павлової [5], Л.О. Штанько [9] та інших. Водночас подальшого дослідження потребують фактори, які впливають на інвестиційну привабливість підприємства та підвищують їі. У більшості розроблених методик з оцінки інвестиційної привабливості підприємства не приділяється увага такому фактору, як інтелектуальний капітал. Однак саме інтелектуальна складова частина вартості підприємства формує конкурентні переваги та викликає зацікавленість інвестора.

Формулювання цілей статті. Метою статті є оцінка інтелектуального капіталу підприємства харчової промисловості регіону як фактора, який впливає на інвестиційну привабливість, та розміру цього впливу. Доцільним $€$ визначення заходів із підвищення інвестиційної привабливості підприємства, які спрямовані на залучення нових інвесторів та покращення умов інвестування.

Виклад основного матеріалу дослідження. Для створення переваг підприємства у боротьбі за обмежені інвестиційні ресурси необхідно дослідити фактори, які впливають на інвестиційну привабливість підприємства та їі підвищення. Аналіз джерел засвідчує, що на розвиток інвестиційної привабливості підприємства впливає низка факторів, таких як економічні, соціальні, технологічні (табл. 1).

Отже, на інвестиційну привабливість підприємства впливають зовнішні і внутрішні фактори. Суб'єкту господарювання важко впливати на зовнішнє середовище, його формування і розвиток. Водночас фактори внутрішнього середовища повністю залежать від результатів фінансово-господарської діяльності підприємства та є важелем впливу на його інвестиційну привабливість. Низка науковців стверджує, що для привернення уваги інвесторів доцільно розглянути такий складник діяльності підприємства, як інтелектуальний капітал. На думку О.С. Павлової [5], інтелектуальний капітал підвищує ринкову вартість підприємства та покращує його репутацію. Інтелектуальний капітал - це інтелектуальний ресурс підприємства (знання, досвід, можливості), який взаємодіє з організаційним складником і ринковим середовищем та за умови ефективного використання конвертується у додаткову вартість, забезпечуючи конкурентоспроможність суб'єкта господарювання [6].

Оцінка інвестиційної привабливості підприємства у дослідженні грунтується на розрахунку комплексного показника, який розраховується як сума бальних оцінок системи репрезентативних коефіцієнтів, що характеризують різні аспекти ефективності діяльності, стійкості фінансового стану і платоспроможності підприємства.

Під час визначення інвестиційної привабливості підприємства аналізуються групи показників, які іiі характеризують, та рівень сформованості інтелектуального капіталу (результатами попередніх досліджень доведено, що названий показник також впливає на інвестиційну привабливість підприємства) [6]. У першу об'єднані показники ефективності діяльності (рентабельність продажу, рентабельність активів, рентабельність оборотних активів, рентабельність власного капіталу, коефіцієнт зносу); у другу - показники фінансового стану (коефіцієнт забезпеченості оборотних активів власними коштами, коефіцієнт автономіі); у третю - показники ліквідності та платоспроможності (коефіцієнт поточної ліквідності, коефіцієнт швидкої ліквідності, коефіцієнт абсолютної ліквідності). Окреслена система показників оцінює можливість підприємства одержувати прибутки, імовірність повернення вкладених інвесторами коштів та спроможність до впровадження інновацій.

На основі експертних досліджень була розроблена бальна оцінка параметрів, що входять у рейтингову оцінку інвестиційної привабливості (табл. 2). При цьому оцінюється величина первинного параметра (за певний рік), потім отриманий бал коригується з урахуванням динаміки [3; 9]. Первинні параметри цієї методики такі: «добре»-3 бали; «задовільно» - 2 бали; «в межах допустимого значення» - 1 бал; «незадовільно» - 0 балів. Коригування на динаміку показників: «дуже позитивна» $(+50 \%)$ - плюс 20\%; «позитивна» (від +10\% до 50\%) плюс 10\%; «стабільна» (від -10\% до $+10 \%$ ) - 0; «негативна» (від $-50 \%$ до -10\%) - мінус 10\%.

Далі проводиться оцінка інвестиційної привабливості підприємства за кількістю розрахованих балів і скоригованих з урахуванням динаміки. Таким чином, інвестор отримує обгрунтування прибутковості різних альтернатив вкладення фінансових ресурсів 3 урахуванням обмежень та вимог щодо окупності інвестицій.

Таблиця 1 - Фактори, що впливають на інвестиційну привабливість підприємства

\begin{tabular}{|c|c|c|}
\hline \multicolumn{3}{|c|}{ Фактори } \\
\hline Інституціональні & Економічні & Соціальні \\
\hline $\begin{array}{l}\text { - стабільність внутрішньої політики } \\
\text { підприємства; } \\
\text { - гарантія прав і свобод працівника; } \\
\text { - ступінь державного втручання в } \\
\text { економіку підприємства; } \\
\text { - торговельна політика підприємства; } \\
\text { - діяльність підприємства відповідно } \\
\text { до чинного нормативно-правового } \\
\text { законодавства; } \\
\text { - розвиток комунікаційної мережі на } \\
\text { підприємстві. }\end{array}$ & $\begin{array}{l}\text { - темпи росту обсягів валової продукції } \\
\text { підприємства; } \\
\text { - рентабельність активів, виробництва та продажів; } \\
\text { - фінансовий стан та фінансові ризики; } \\
\text { - ймовірність банкрутства; } \\
\text { - рівень інформаційного забезпечення та } \\
\text { доступу до глобальних мереж; } \\
\text { - вартість ресурсного потенціалу та } \\
\text { ефективність його використання; } \\
\text { - рівень сформованості та вартість } \\
\text { інтелектуального капіталу підприємства. }\end{array}$ & $\begin{array}{l}\text { - рівень освіченості та } \\
\text { кваліфікаційної підготовки } \\
\text { працівників; } \\
\text { - активність профспілок на } \\
\text { підприємстві; } \\
\text { - соціально-психологічний } \\
\text { клімат на підприємстві; } \\
\text { - стилі та форми управління на } \\
\text { підприємстві. }\end{array}$ \\
\hline
\end{tabular}

Джерело: складено авторами на основі [2; 3$]$ 
Таблиця 2 - Бальна оцінка параметрів інвестиційної привабливості підприсмства

\begin{tabular}{|l|c|c|c|c|}
\hline \multicolumn{1}{|c|}{ Показники } & \multicolumn{3}{c|}{ Оцінка } \\
\cline { 2 - 5 } & добре & задовільно & $\begin{array}{c}\text { в межах } \\
\text { допустимого } \\
\text { значення }\end{array}$ & незадовільно \\
\hline Рентабельність продажу, \% & & $5-20$ & $0-5$ & $-20-0$ \\
\hline Рентабельність активів, \% & $>15$ & $5-15$ & $0-5$ & $-10-0$ \\
\hline Рентабельність власного капіталу, \% & $>45$ & $15-45$ & $0-15$ & $-30-0$ \\
\hline Частка зносу основних засобів, \% & $<20$ & $20-30$ & $30-45$ & $45-60$ \\
\hline Рентабельність оборотних активів, \% & $>30$ & $10-30$ & $0-10$ & $-20-0$ \\
\hline Коефіцієнт поточної ліквідності & $>1,3$ & $1,15-1,3$ & $1-1,15$ & $0,9-1$ \\
\hline Коефіцієнт швидкої ліквідності & $>1$ & $0,8-1$ & $0,7-0,8$ & $0,5-0,7$ \\
\hline Коефіцієнт абсолютної ліквідності & $>0,3$ & $0,2-0,3$ & $0,15-0,2$ & $0,1-0,15$ \\
\hline Коефіцієнт забезпеченості оборотних активів власними коштами & $>0,22$ & $0,12-0,22$ & $0-0,12$ & $-0,11-0$ \\
\hline Коефіцієнт автономії, \% & $>0,50$ & $0,20-0,50$ & $0,10-0,20$ & $0,03-0,10$ \\
\hline Рівень сформованості інтелектуального капіталу & $0,9-1,0$ & $0,75-0,899$ & $0,6-0,749$ & $0-0,599$ \\
\hline
\end{tabular}

Джерело: складено авторами на основі [3]

Нами проведена оцінка інвестиційної привабливості ПрАТ «Чумак» (табл. 3). ПрАТ «Чумак»-підприємство національного рівня, основна діяльність якого виробництво продуктів харчування (кетчупів, соусів, майонезів, томатної пасти, соків, консервованих овочів та макаронних виробів). Підприємство розташоване в екологічно чистій місцевості, що гарантує високу якість продукції. На підприємстві розроблені і впроваджені системи менеджменту якості та безпечності харчової продукції, сертифікований їх виробничий процес. Підприємство має не лише виробничі потужності для переробки томатів, але і власну сировинну базу. Підприємство впроваджує інноваційні технології не лише вирощування сільськогосподарської продукції (змонтована і використовується система крапельного зрошення), а і іï переробки (впроваджена лінія пастеризації інгредієнтів та замінений цукор на стевію тощо). Підприємство реалізує продукцію не лише на теренах України, а і за кордон: в Угорщину, Польщу, Чехію, Ізраїль, Іспанію, Прибалтійські республіки, Казахстан, Грузію, Канаду та США. Підприємство має зареєстровану торгову марку «Чумак», слоган «З лану до столу»; постійно сприяє підвищенню кваліфікації персоналу (штат постійних працівників коливається в межах 800 осіб), турбується про соціальний захист робітників. Вартість нематеріальних активів підприємства за досліджуваний період зросла на 8416 тис. грн.

Наведені в табл. 3 розрахунки свідчать, що найвища інвестиційна привабливість ПрАТ «Чумак» за досліджуваний період спостерігалась у 2019 році. Основною причиною стало підвищення рівня інтелектуального капіталу підприємства до 0,75 , а 3 урахуванням коригування на динаміку цього показника $-0,9$.

Для визначення впливу рівня сформованості інтелектуального капіталу на інвестиційну привабливість ПрАТ «Чумак» нами використаний кореляційно-регресійний аналіз. Нехай зв'язок між ознаками описується таким лінійним рівнянням регресії (1):

$$
\mathrm{y}=\mathrm{a}_{0}+\mathrm{a}_{1} \mathrm{x}
$$

де у-інвестиційна привабливість підприємства, бали;

x - рівень сформованості інтелектуального капіталу підприємства.

Дані для розрахунку наведені в табл. 4.

Таблиця 3 - Оцінка інвестиційної привабливості ПрАТ «Чумак»

\begin{tabular}{|l|c|c|c|c|c|c|}
\hline \multicolumn{1}{|c|}{ Показники } & $\mathbf{2 0 1 7} \mathbf{p .}$ & $\begin{array}{c}\text { Бальна } \\
\text { оцінка }\end{array}$ & $\mathbf{2 0 1 8}$ p. & $\begin{array}{c}\text { Бальна } \\
\text { оцінка }\end{array}$ & $\mathbf{2 0 1 9}$ p. & $\begin{array}{c}\text { Бальна } \\
\text { оцінка }\end{array}$ \\
\hline Рентабельність продажу, \% & 31 & 3 & 31 & 3 & 31 & 3 \\
\hline Рентабельність активів, \% & 0 & 0 & 17 & 3 & 74 & 3 \\
\hline Рентабельність власного капіталу, \% & 0 & 0 & 5 & 1 & 18 & 2 \\
\hline Рентабельність оборотних активів, \% & 0 & 0 & 7 & 1 & 16 & 2 \\
\hline Частка зносу основних засобів, \% & 85 & 0 & 85 & 0 & 85 & 0 \\
\hline Коефіціснт поточної ліквідності & 1,32 & 3 & 1,47 & 3 & 0,6 & 0 \\
\hline Коефіцієнт швидкої ліквідності & 0,6 & 0 & 0,6 & 0 & 0,3 & 0 \\
\hline Коефіціснт абсолютної ліквідності & 0,006 & 0 & 0,005 & 0 & 0,011 & 0 \\
\hline $\begin{array}{l}\text { Коефіціснт забезпеченості оборотних активів } \\
\text { власними коштами }\end{array}$ & 1,35 & 3 & 1,58 & 3 & 0,8 & 3 \\
\hline Коефіціснт автономії & 0,56 & 3 & 0,5 & 3 & 0,9 & 3 \\
\hline Рівень сформованості інтелектуального капіталу & 0,21 & 0 & 0,43 & 0 & 0,9 & 3 \\
\hline Сума балів & $\mathrm{x}$ & 12 & $\mathrm{x}$ & 17 & $\mathrm{x}$ & 19 \\
\hline
\end{tabular}

Джерело: складено авторами на основі розрахунків 
Таблиця 4 - Основні показники для кореляційно-регресійного аналізу

\begin{tabular}{|c|c|c|}
\hline Роки & $\begin{array}{c}\text { Рівень інвестиційної привабливості } \\
\text { ПрАТ "Чумак" }\end{array}$ & $\begin{array}{c}\text { Рівень сформованості } \\
\text { інтелектуального капіталу }\end{array}$ \\
\hline 2017 & 12 & 0,21 \\
\hline 2018 & 17 & 0,43 \\
\hline 2019 & 19 & 0,9 \\
\hline
\end{tabular}

Джерело: складено авторами

Таблиця 5 - Результати кореляційного аналізу інвестиційної привабливості ПрАТ «Чумак»

\begin{tabular}{|l|c|c|}
\hline \multicolumn{1}{|c|}{ Показники } & $\begin{array}{c}\text { Рівень інвестиційної } \\
\text { привабливості ПрАТ "Чумак" }\end{array}$ & $\begin{array}{c}\text { Рівень сформованості } \\
\text { інтелектуального капіталу }\end{array}$ \\
\hline Рівень інвестиційної привабливості ПрАТ "Чумак" & 1 & 0,900979151 \\
\hline Рівень сформованості інтелектуального капіталу & 1 \\
\hline
\end{tabular}

Джерело: складено авторами на основі розрахунків

Для аналізу опрацьовані показники статистичної і фінансової звітності за 2017-2019 рр. Для перевірки впливу фактора на результативний показник за допомогою MS Excel (надбудова «Аналіз даних / Кореляція») розрахований коефіцієнт кореляції (табл. 5).
3 табл. 5 випливає, що між інвестиційною привабливістю підприємства та рівнем сформованості його інтелектуального капіталу є тісний зв'язок.

Наступним етапом $є$ проведення регресійного аналізу. Для його проведення використано MS Excel (надбудова «Аналіз даних / Регресія»), результати наведені в табл. 6-8.

Таблиця 6 - Результати регресійної статистики

\begin{tabular}{|l|c|}
\hline \multicolumn{1}{|c|}{ Показники } & Значення \\
\hline Множественный R & 0,900979151 \\
\hline R-квадрат & 0,811763431 \\
\hline Нормированный R-квадрат & 0,623526862 \\
\hline Стандартная ошибка & 2,212272766 \\
\hline
\end{tabular}

Джерело: складено авторами на основі розрахунків

Нормований коефіцієнт детермінації дорівнює 0,62353. Це свідчить про те, що зміна рівня сформованості інтелектуального капіталу підприємства спричиняє зміну його інвестиційної привабливості на 62,4\%.

Таблиця 7 - Результати дисперсійного аналізу

\begin{tabular}{|l|c|c|c|c|c|}
\hline \multicolumn{1}{|c|}{ Показники } & df & SS & MS & F & Значущість F \\
\hline Регресія & 1 & 21,10584921 & 21,10584921 & 4,312464 & 0,285699 \\
\hline Залишок & 1 & 4,894150792 & 4,894150792 & & \\
\hline Всього & 2 & 26 & & & \\
\hline
\end{tabular}

Джерело: складено авторами на основі розрахунків

Порівняємо отримані дані з табличними за критерієм Фішера: F-критерій = 4,31, f табл. =0,285699. Отже, за результатами розрахунків ця модель надійна, рівняння регресії значуще.

Таблиця 8 - Результати регресійного аналізу

\begin{tabular}{|l|c|c|c|c|}
\hline \multicolumn{1}{|c|}{ Показники } & Коефіціснти & Стандартна помилка & т-статистика & Р-значення \\
\hline Ү-перетин & 11,26884894 & 2,611871176 & 4,314473487 & 0,144994 \\
\hline Рівень сформованості інтелектуального капіталу & 9,216528039 & 4,438176875 & 2,076647303 & 0,285699 \\
\hline
\end{tabular}

Джерело: складено авторами на основі розрахунків

Порівнюючи показники Р-значення, визначено, що коефіцієнти $є$ не нульовими, оскільки всі значення менші за 0,5, що свідчить про наявність впливу факторної ознаки на результативну.
За результатами кореляційно-регресійного аналізу можна стверджувати, що збільшення рівня сформованості інтелектуального капіталу підприємства приводить до підвищення його інвестиційної привабливості. 
Рівняння лінійної регресії (2) наведено у вигляді:

$$
\mathrm{y}=11,26884894+9,22 \mathrm{x}
$$

Аналізуючи отриману модель, можна стверджувати, що за збільшення рівня інтелектуального капіталу на 0,1 інвестиційна привабливість підприємства зросте на 9,22 бала.

Висновки. В умовах «економіки знань» рівень сформованості і вартість інтелектуального капіталу мають для інвесторів важливе інформативне значення, бо забезпечують норму прибутковості вищу, ніж традиційні фінансові показники. Залучення нових інвесторів можливе лише у разі покращення умов інвестування та високої конкурентоспроможності об'єкта інвестицій. Під час оцінки інвестиційної привабливості підприємства доцільно використовувати методику, яка враховує вплив інтелектуального капіталу на вказаний показник.

\section{Список використаних джерел:}

1. Бланк И.А. Финансовый менеджмент : Учебный курс. Киев, 2002. 528 с.

2. Бутинко В.В. Інвестиційна привабливість підприємств: економічний зміст та дефініції. Агросвіт. 2013. № 9. С. 61-64.

3. Оцінка кредитоспроможності та інвестиційної привабливості суб'єктів господарювання : монографія / А.О. Спіфанов, Н.А. Дехтяр, Т.М. Мельник та ін.; за ред. А.О. Єпіфанова. Суми, 2007. 286 с.

4. Носова О.В. Інвестицйна привабливість підприємства. Стратегічні пріоритети. 2007. № 1(2). С. 120-126.

5. Павлова О.С. Інтелектуальний капітал як фактор підвищення інвестиційної привабливості підприємств (на прикладі виноробної промисловості). Економічні інновації. 2012. № 47. С. 214-221.

6. Ротань Н.В. Управління розвитком інтелектуального капіталу підприємств : автореф. дис. ... канд. екон. наук : спец. 08.00.04 «Економіка та управління підприємствами»; Харківський нац. техн. ун-т сільського господарства імені Петра Василенка. Харків, 2018. 20 с.

7. Собко О.М. Інтелектуальний капітал і креація вартості підприємства : монографія. Тернопіль, 2016. 444 с.

8. Стригуль Л.С. Особливості формування інвестиційних процесів промислових підприємств в умовах структурних перетворень економіки. Вісник ЖДТУ. Серія : Економічні науки. 2013. Вип. 1(163). С. 333-338.

9. Штанько Л.О. Оцінка інвестиційної привабливості промислових підприємств. Проблеми теорії та методології бухгалтерського обліку, контролю і аналізу. 2013. Вип. 3(30). С. 399-414.

\section{References:}

1. Blank I.A. (2002). Finansovyj menedzhment: Uchebnyj kurs [Financial Management: Training course]. Kiev. (in Ukrainian)

2. Butynko V.V. (2013). Investytsiina pryvablyvist pidpryiemstv: ekonomichnyi zmist ta definitsii [Investment attractiveness of enterprises: economic content and definitions]. Ahrosvit, no. 9, pp. 61-64.

3. Yepifanov A.O. (2007). Otsinka kredytospromozhnosti ta investytsiinoi pryvablyvosti sub'iektiv hospodariuvannia: monohrafiia [Assessment of business entities creditworthiness and investment attractiveness: a monograph] / A.O. Yepifanov, N.A. Dekhtiar, T.M. Melnyk ta in.; za red. A.O. Yepifanova. Sumy: UABS NBU, 286 p. (in Ukrainian)

4. Nosova O.V. (2007). Investytsina pryvablyvist pidpryiemstva [Investment attractiveness of the enterprise]. Stratehichni priorytety, no. 1(2), pp. 120-126.

5. Pavlova O.S. (2012). Intelektualnyi kapital yak faktor pidvyshchennia investytsiinoi pryvablyvosti pidpryiemstv (na prykladi vynorobnoi promyslovosti) [Intellectual capital as a factor in increasing the investment attractiveness of enterprises (on the example of the wine industry)]. Ekonomichni innovatsii, no. 47, pp. 214-221.

6. Rotan N.V. (2018). Upravlinnia rozvytkom intelektualnoho kapitalu pidpryiemstv [Management of intellectual capital development of enterprises]: avtoref. dys. ... kand. ekon. nauk: spets. 08.00.04 «Ekonomika ta upravlinnia pidpryiemstvamy»; Kharkivskyi nats. tekhn. un-t silskoho hospodarstva imeni Petra Vasylenka. Kharkiv, 20 p.

7. Sobko O.M. (2016). Intelektualnyi kapital i kreatsiia vartosti pidpryiemstva: monohrafiia [Intellectual capital and the creation of enterprise value: a monograph]. Ternopil: TNEU, $444 \mathrm{p}$.

8. Stryhul L.S. (2013). Osoblyvosti formuvannia investytsiinykh protsesiv promyslovykh pidpryiemstv v umovakh strukturnykh peretvoren ekonomiky [Features of formation of investment processes of industrial enterprises in the conditions of structural transformations of economy]. Visnyk ZhDTU. Seriia: Ekonomichni nauky, vol. 1(163), pp. 333-338.

9. Shtanko L.O. (2013). Otsinka investytsiinoi pryvablyvosti promyslovykh pidpryiemstv [Assessment of investment attractiveness of industrial enterprises]. Problemy teorii ta metodolohii bukhhalterskoho obliku, kontroliu i analizu, vol. 3(30), pp. $399-414$. 
Komlichenko Oksana, Rotan Natalia

Odessa National Polytechnic University

\section{INTELLECTUAL CAPITAL AS A FACTOR OF INFLUENCE ON THE ENTERPRISE INVESTMENT ATTRACTIVENESS}

In the context of Ukraine's integration into the world economic space, attention is growing to one of the key attracting investment resources characteristics - the enterprise investment attractiveness and ways to increase it. Therefore, the study of factors influencing the enterprise investment attractiveness growth is relevant. The article defines the concepts of "the enterprise investment attractiveness" and "intellectual capital". Factors that affect the enterprise investment attractiveness, including economic, social, technological ones, are outlined. However, in order to attract the investors' attention, it is advisable to consider such a component of the enterprise as intellectual capital. A point assessment of the enterprise investment attractiveness, which takes into account not only the results of financial and economic activities (indicators of efficiency, financial condition, liquidity and solvency), but also the intellectual capital formation level. These calculations show that the main factor in increasing the enterprise investment attractiveness is its intellectual capital formation level growth. With the help of correlation-regression analysis, the intellectual capital influence on the food industry enterprise investment attractiveness level is determined. To check the impact of the factor on the performance indicator using MS Excel, a correlation coefficient was calculated, which indicates that there is a close relationship between the enterprise investment attractiveness and its intellectual capital formation level. The regression analysis results indicate the presence of the factor feature influence on the effective feature, and the change in the level of the enterprise intellectual capital formation causes a change in its investment attractiveness by $62.4 \%$. According to the results of calculations, the model is reliable, the regression equation is significant. Analyzing the obtained model, we can say that with an increase in the level of intellectual capital by 0.1, the investment attractiveness of the enterprise will increase by 9.22 points.

Key words: real attractiveness, intellectual capital, influence factor, correlation-regression analysis.

JEL classification: C15, E22, G23, O34 